\title{
Respect for Nature of Alas Kobong Folklore in Pacitan Regency and Relevance to Learning Literature in SMP Adiwiyata (Ecocriticism Studies)
}

\author{
Latifah Mutiara Sari ${ }^{1}$, Sarwiji Suwandi ${ }^{2}$, Sahid Teguh Widodo ${ }^{2}$ \\ ${ }^{I}$ Master Student of Sebelas Maret University, Surakarta, Indonesia \\ ${ }^{2}$ Teacher Training and Education Faculty of Sebelas Maret University, Surakarta, Indonesia \\ latifahmutiarasari@student.uns.ac.id
}

\begin{abstract}
This study aims to interpret ekokritik literary theory by expressing the value of environmental wisdom focused on respect for nature of fo Alas Kobong Folklore in Pacitan Regency. Ekokritik literature to examine the application of this folklore is through data classification based on the moral principles of environmental wisdom focused on respect for nature. The shape of this research is descriptive qualitative with an interactive approach to data sources transcript of interviews about Alas Kobong folklore of participants in Pacitan Regency. Data were collected through interviews, observation, documentation, field notes and transcriptions. There are three aspects of data analysis techniques, namely the description, analysis, and interpretation. The results of this study found five data contained in a respectful attitude towards nature which is included in the value of environmental wisdom of Alas Kobong folklore in Pacitan Regency. In addition, the folklore of Alas Kobong can also implies learning literature junior secondary school Adiwiyata curriculum.
\end{abstract}

Keyword : Alas Kobong; Folklore; Values Environmental Wisdom; Ekokritik; Learning Literature

\section{Introduction}

Humans have an important role in the preservation of natural surroundings, especially the natural surroundings that have noble values that bemanfaat for future life. Garrard (2004) said that the importance of ecological knowledge not only to see the harmony and stability of the environment, but also to determine the attitudes and behavior of human beings.

But it is the case today, a lot of the Man who neglect the preservation of nature, so do not know the stories until the culture left by ancestors who mengamdung values of wisdom for being defeated by the growing technological advances.

Keraf (2010) argue that environmental damage can be rooted in the philosophy or the human perspective about himself, or the natural environment, and its place in the overall ecosystem. To that end, ekokritik provide space and consciousness in the literary world to integrate the environment into something interesting to read and discuss.

Analysis of the expanded interdisciplinary ekokritik other disciplines, namely literature, culture, philosophy, sociology, psychology, history of environmental, political and economic, and religious studies. In this connection, Buell (2005) says, "Might ecocriticism succinctiy be defined as the study of the relation between literature and environment conducted in a commitment to environmental praxis".

Research ethics notice explaining the human relationship with nature, where man is regarded as moral agents because their consciences (Retnowati, et al, 2014); have examined the equation objects related to nature like other researchers who uncover the nature of the role concept Malays view by type in the novel defeated sang sapurba Pe Ediruslan work Amanriza (Bourdeau, 2004); and other researchers indicate to know the shape and implementation of sustainable tourism based on environmental wisdom (Laksmi and Wisnumurti, 2019). From several previous studies it appears that in this study focuses on the value of environmental 
wisdom in folklore Alas Kobong in the village of Kendal, District Punung, Pacitan that made the difference as well as the renewal of previous research.

Ekokritik literature to examine the application of this folklore is through data classification based on the moral principles of environmental wisdom. The environmental wisdom of moral principles such as respect for nature, the attitude of responsibility towards nature, the principle of compassion and care, the principle of not harming nature, as well as the principles of a simple life in harmony with nature (Keraf, 2010).

According Daulay (2014) folklore is a culture that has been attached to the community. Therefore, plot, language, traditions and culture in the story often has a closeness with their owners or even in the form of its reflection. While environmental ethics is used to save the environment by human moral responsibility (Laksmi, 2019). Thus, the study of environmental ethics is important.

One folklore contained in Pacitan is Alas Kobong in the village of Kendal, District Punung, Pacitan. Behind the name of the village where there is folklore that enveloped, like the story about the origin of the forest fires and public confidence about the mysterious animal deer are the gatekeepers butane. Therefore, the above-mentioned, various traditions and art is maintained and preserved because it describes a story of the past were dedicated as the foundation of the noble values of life and should be studied more in depth up to helpful for future life.

With regards to learning literature, story of Alas Kobong will be used for the development of teaching materials on the subjects of Indonesian junior high School of Adiwiyata curriculum.

\section{Research Methods}

The research is a qualitative descriptive study. Moleong (2007) states that qualitative research is a research intends to understand the phenomenon of what is experienced by the object of research by way of description in the form of words and language, in a specific context by harnessing natural and right various natural methods.

The data in this study is an excerpt folklore and the results obtained from the transcript of the interview participants. The data source of this research is folklore of Alas Kobong in Pacitan Regency. The collection of data through interviews, observation, documentation, field notes and transcriptions (Creswell, 2014). Data analysis techniques used in this study is an interactive model. Interktif analysis including data collection, data reduction, data presentation, and data verification.

Description of the data in this study include the process of drafting, developing and write. The first phase, researchers compiled objectively and focus on a series of stories, the second stage, the authors develop a story and focus on the aspects of respect for nature and then described in terms of an objective description. The third phase, the researchers interpret the data and interpret findings on moral values environmental wisdom folklore of Alas Kobong in Pacitan Regency.

This study uses data triangulation that (1) triangulation source, (2) triangulation method, (3) triangulation theory. Triangulation of data to achieve understanding and deeper knowledge generated by research directly in the field and conduct an investigation to obtain the detailed meaning and validation of data (Creswell, 2014) 


\section{Result and Discussion}

Results of this study to describe and explain the value of environmental wisdom focused on one aspect, namely respect for nature of Alas Kobong Folklore and utilization in Indonesian teaching materials in junior Adiwiyata

\subsection{Respect Against Nature}

Respect for the natural look that humans have a moral obligation to appreciate and respect the rights of all beings both biological and non-biological to be, live, grow, and develop (Keraf, 2010). In the perspective of environmental ethics, respect for nature as an ecological element based on the people's awareness of the intrinsic value of nature, that nature has value in itself that he has the right to be respected.

First Data is "Locals to believe in that Alas Kobong a sacred place". From these data explain that the attitude of responsibility of Waga village of Kendal will trust in the Foundation Kobong and stories that enveloped him, so residents are maintaining of any bad behavior around the Alas Kobong.

The second data is "People are passing through or visiting Alas Kobong should behave, so that no bad things happen to him".From these data explain, villagers Kendal, really believe it and respect it by continuing to maintain to remain polite behavior when around Alas Kobong.

And the third is "held at least once a month voluntary work routine cleaning Kobong Alas area to keep clean surroundings". From these data menunujukan Kendal village residents who menghirmati nature, and berusha to continue to care for and preserve the stories and beliefs that enveloped him.

Data fourth "Not allowed to hunt deer coming and ran toward Kobong Alas, because according to the trust the people around, the deer was the guard Alas Kobong which at times shown to him in the presence of the villagers of Kendal". From these data make it clear that, in addition to the preservation of nature around Alas Kobong, Kendal Village residents also believe animal related story Deer are often seen walking and running to Alas Kobong for not disputed, and let it be.

Data fifth "Alas around Kobong have a large tree which is believed to be the resting place of Kyai Mojo while searching for his son and puti Pabru, Kendal village residents believe that and keep the tree without any intention to be overthrown". From these data suggested that the villagers of Kendal trust and respect of nature around Alas Kobong, and trying to preserve it.

Based on the findings, the researchers concluded that the folklore Alas Kobong of Pacitan contain certain values of wisdom environment focused on one element of which is respect for the nature that has been presented in this study, the value of environmental wisdom reflects the simplicity of community life together and in harmony with nature as one an attitude of respect and safeguard of nature with local people.

\subsection{Learning Literature}

Learning literature in junior secondary school Adiwiyata especially Indonesian subjects that use the curriculum in 2013, entirely text based on any material. In accordance with the results of research used in the development of teaching materials in junior secondary school Adiwiyata, folklore can be used as teaching materials on teaching literature in junior high schools, which discusses folk ceita in Indonesian Compulsory subjects only in the seventh 
grade. Material folklore exist at KD 3.11, 4.11. Folklore material covered include: (1)Feature fable / legend relating to the environment, (2) Step understand the story fable, (3) Step recounting the contents of fable / legend.

From the findings, the material folklore Alas Kobong if diajarakan in class VII in SMP Adiwiyata very precisely by conducting interpret and examine the contents of folklore that are directly related to the environment in accordance with the sulking on the school curriculum based environment.

\section{Conclusion}

Found five data from the value of environmental wisdom, especially in the aspect of respect for nature are still preserved by the villagers of Kendal, a respectful attitude towards nature and the locals necessarily protect what they believe about the story Alas Kobong, thus preserving what has been The sakralkan in the environment. In addition to those mentioned above, the Alas Kobong folklore can also be used as teaching materials in teaching literature in junior secondary school Adiwiyata in class VII.

\section{Acknowledgments}

Thanks to all those who have helped contribute and engage in the preparation of the article, especially the supervisor and the editorial board of the journal. Hope writer, hopefully this study will contribute in particular the area of education in the state and nation across the globe.

\section{Reference}

Creswell, JW 2013. Qualitative Inquiry and Research Design Choosing Among Five Traditions. London: SAGE Publications, Inc.

Danandjaja, J. 1991. Folklore Indonesia: Science gossip, tales, and others. Jakarta: PT Pustaka Utama Grafiti.

N. Dewi. 2019. "Ekokritik in Indonesian Literature: Literary Studies Favor," Adab. J. Bhs. and Literature, vol. 15, no. 1, p. 19.

A. Retnowati, E. Anantasari, MA Marfai, and A. Dittmann, "Environmental Ethics in Local Knowledge Responding to Climate Change: An Understanding of Seasonal Traditional PranotoMongso and its Phenology Calendar in Karst Areas of Gunung Kidul, Yogyakarta, Indonesia," Environ Procedia, Sci., Vol. 20, pp. 785-794, 2014.

P. Bourdeau, "The man-nature relationship and environmental ethics," in Journal of Environmental Radioactivity, 2004, vol. 72, no. 1-2, pp. 9-15.

Aars Laksmi and AAGO Wisnumurti, "Sustainable Tourism Model Based on Environmental Wisdom in Penglipuran Tourism Village, Subdistrict Kubu, Bangli," 2019.

Garrard, G. (2004) Ecocriticisme. USA: Routlegge.

U. Le Guin, "The Carrier Bag Theory of Fiction," in The Ecocriticism Reader: Landmarks in Literary Ecology, 1996, pp. 149-154.

US Keraf Environmental Ethics. Jakarta: PT Kompas Media Nusantara 2010. 
T. Suwondo, "Works Fiction Ali Akbar Navis," Al-Qalam, vol. 8, pp. 59-64, 1989.

JW Creswell, Qualitative Inquiry and Research Design: Choosing Among Five Approaches. 2013.

LJ Moleong, "Qualitative Research Methodology (Revised Edition)," in PT. Teens Rosda paper, 2017.

Laksmi, Aars and Wisnumurti, AAGO (2019) 'Sustainable Tourism Model Based on Environmental Wisdom in Penglipuran Tourism Village, Subdistrict Kubu, Bangli', in. doi: 10.4108 / eai.21-9-2018.2281140.

A. TEEUW, Literature and Literary Studies: Introduction to the Theory of Literature. Jakarta: The World Pustaka Jaya, 1984.

AB Lord, The Singer of Tale. New York: Atheneum, 1976.

Sutopo, B. and Mustafa, A. 2015. Local Wisdom in Folklore Pacitan. Surakarta: Oase Reader. 